\title{
UNREINFORCED MASONRY STRUCTURES' SEISMIC IMPROVEMENT WITH F.R.C.M. : THE EXPERIENCE OF THE VANVITELLIAN PALAZZO MURENA OF PERUGIA
}

\author{
RICCARDO LIBEROTTI $^{*}{ }^{*}$ FEDERICO CLUNI $^{1}$ AND VITTORIO GUSELLA $^{1}$ \\ ${ }^{1}$ Department of Civil and Environmental Engineering \\ University of Perugia (Italy) \\ Via Duranti, 06125 - Perugia, Italy \\ e-mail: riccardo.liberotti@unipg.it (*corresponding author), federico.cluni@unipg.it, \\ vittorio.gusella@unipg.it
}

Keywords: Heritage Structures, Masonry Building, Numerical Modelling, F.R.C.M. Details

\begin{abstract}
The aim of the contribution is to illustrate strengthening design in regard to the conservation of Palazzo Murena in Perugia, designed in the eighteenth century by the prominent Architect Luigi Vanvitelli. Starting from an accurate historical analysis and taking into account experimental campaign and results of numerical analysis, the vulnerable elements of the construction have been highlighted. A local reinforcement intervention is proposed with the aim of retain the historical value of the architectural characteristics; this consists of the application of plaster with Fiber Reinforced Cementitious Matrix, F.R.C.M., to achieve an adequate strength, without adding supplemental weight to the masonry structure and therefore avoiding an increase of the seismic vulnerability. The benefits of the application of F.R.C.M. materials, also with respect to different reinforcement techniques are broaden.
\end{abstract}

\section{INTRODUCTION}

Owing to the recent earthquakes that affected central Italy, in particular the Umbria region, the University of Perugia activated a research program aimed at the seismic vulnerability assessment of historic buildings under its ownership and management. This activity also involved the architectural complex of Palazzo Murena that hosts the headquarters of the University of Perugia, Fig. 1. This aggregate is composed by three adjacent buildings: Palazzo Murena (former monastic complex), the ex-accountancy office and the church of Montemorcino Nuovo or church of the University, Fig. 2. With reference to Palazzo Murena, in a previous contribution [1] the basic correlations among the historical knowledge, the seismic vulnerability assessment and the widespread experimental tests campaigns have been addressed in the framework of the safeguard of this iconic building. The seismic analysis [1], by macroelement, proved the good global behaviour of the existing masonry structure anyway highlighting, according to the Italian Building Code [2, 3], that Palazzo Murena ranks in a state deserving to be seismic improved in order to enhance its safety. In addition, during the analysis, the presence of a peculiar structural shape in elevation, influencing the building's seismic behaviour, has been observed and addressed as a possible trigger to the activation of local mechanisms. The present work is aimed to illustrate the proposal of reinforcement with F.R.C.M. composite materials. The contribution has been organized as follows. In Sec. 2 the 
outcomes of a depth historical investigation of Palazzo Murena, in relation to the design criteria of Luigi Vanvitelli, are reported. The outcomes of a survey and experimental campaign are reported in Sec. 3. From these studies and also considering the result of a vulnerability analysis [1] the interventions conceived in order to increase the safety level regarding the seismic behaviour of Palazzo Murena are described in Sec.4.

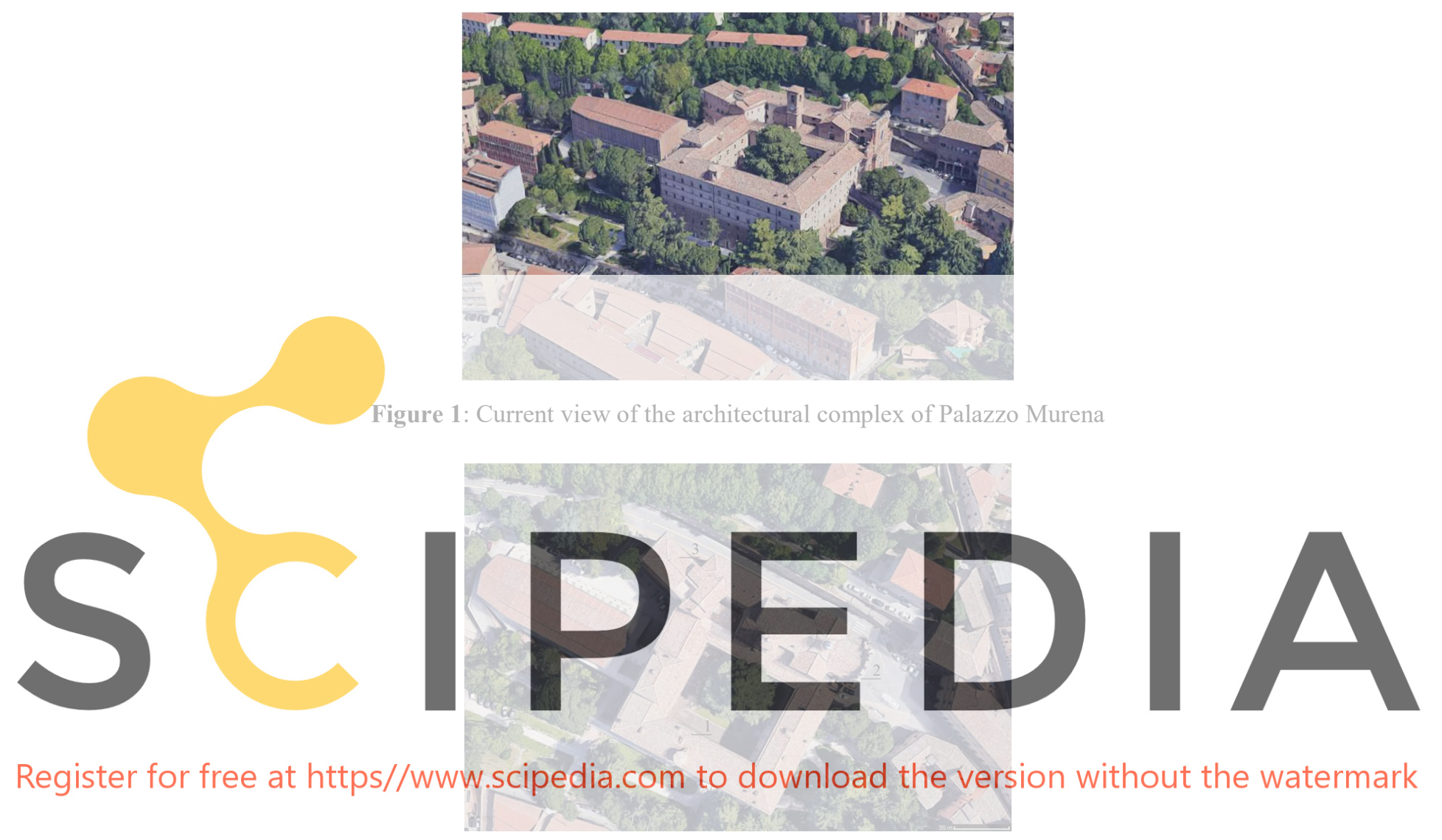

Figure 2: Composition of the architectural complex: 1) Palazzo Murena; 2) University Church; 3) Ex-Accountancy

\section{HISTORICAL INSIGHTS}

Palazzo Murena was once an Olivetan monastic complex, called Monte Morcino Nuovo following the transfer from its former seat of Monte Morcino Vecchio, outside Santa Susanna, to the current University's square. The monastery and the church of the Olivetans have been designed by Luigi Vanvitelli and completed by his pupil Carlo Murena, from whom the palace takes its current name. The Vanvitellian contribution to the project of the Monte Morcino Nuovo is witnessed by various bibliographical and archival historical sources [4-7]; between these stands out the biography, dedicated to the architect, that was written by the eponymous nephew in the early years of the nineteenth century [4] in which it is listed, among the works carried out by Vanvitelli, the façades project of the church and monastery of Perugia. In addition, it is reported that the Architect was called to Perugia to build the church and monastery of the Olivetans while he was still working in Ancona and so the palace, whose drawings are 
still preserved in Caserta, was later completed by the aforementioned Carlo Murena. In 1740 the works began and concluded in 1762 a few years before the confiscation of the monastery in favour of the University of Perugia; the total expenses were around 68.500 scudi (far from what initially planned). In 1810 the monastery passed to the University and in 1813 also the Drawing Academy found space within the monastery. With the return of the papal government in 1814, the University had to defend itself from the charge of usurpation and pleaded the Pope not to reclaim the building. Later Pius VII confirmed the University's property entrusting its management to the professors Luigi Canali and Pietro Vermiglioni in exchange, however, of a regular annual tribute of 200 scudi to be paid to the Olivetans. With the "Regolamento degli studi", issued by Leone XII in 1824, the University of Perugia became a State's University with Rector Luigi Canali. In 1860 the University passed to the Italian Government and its neighbourhood was thus evolving into a true "university campus" conditioning also the viability and the typology of the urban settlements [5], Fig. 3.

A considerable number of earthquakes occurred in the area of Perugia since the construction of Palazzo Murena; on this issue, considering the last centuries, a complete report has been drawn [1]. After the seismic event of 1997, the building was interested by reinforcement interventions primarily aimed at the consolidation of its northwest portion. During time, the building has been affected by variations, also in its end use, which reshaped its architecturalstructural asset many times. Currently the palace is the "headquarter" of the University of Perugia and of the administrative offices.
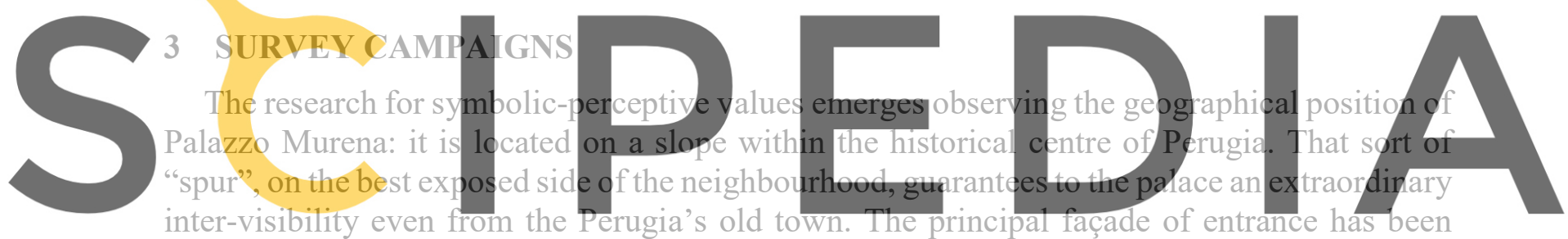
inter-visibility even from the Perugia's old town. The principal façade of entrance has been

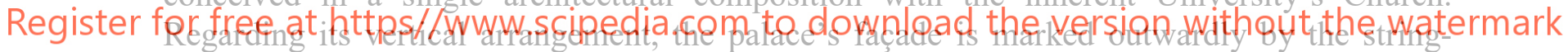
courses corresponding to the floors, reflecting some of the proportions and locations of the inner masonry elements (vauits' position, wall's heights etc.).

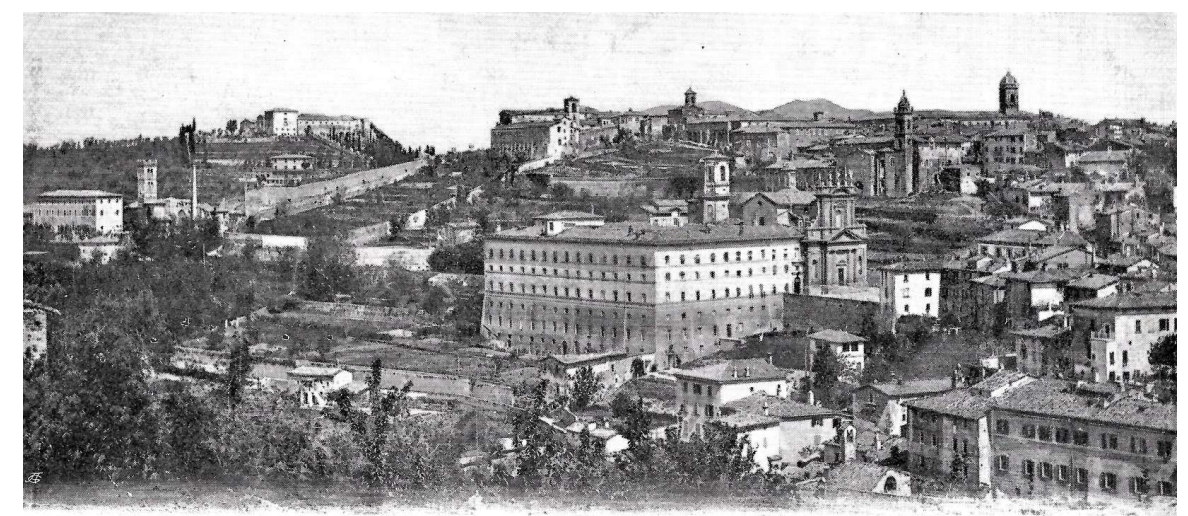

Figure 3: Picture postcard of Perugia's view in the early of $900^{\text {th }}$; in the center stands out Palazzo Murena. Extracted by the private collection of Alterocca (Terni) 
The ground floor is a hollow rectangle with external dimensions about $60 \mathrm{~m} \times 48 \mathrm{~m}$ and inner dimensions, due to the presence of the cloister, about $30 \mathrm{~m} \times 33 \mathrm{~m}$. The heights of the different levels are: $4.80 \mathrm{~m}$ for the third basement, $4.10 \mathrm{~m}$ for the second basement, $3.80 \mathrm{~m}$ for the first basement, $4.75 \mathrm{~m}$ for the ground floor, $3.10 \mathrm{~m}$ for the mezzanine floor and $6.00 \mathrm{~m}$ for the first floor. Therefore, the layout extension of the building varies from level to level, indicating an accentuated vertical asymmetry especially regarding the composition in elevation of the south and east wings of the palace. Indeed, the ground floor plus the mezzanine floor encumber a total height comparable to the lateral corridor's one. This masonry cluster of vaulted rooms, combining such different floors' heights, creates situations, in the mezzanine, marked out by the presence of some carrying walls resting on the top of the barrel vaults, Fig. 4. This peculiarity, that once housed the monks' cells and the relative corridor of distribution, is not the result of a supplements following the original realization of the building factory but, thanks to the historical investigations conducted in the state archive of Perugia [7], it has proved to be perfectly coeval with the design genesis operated by Luigi Vanvitelli. The structure proposed is an example of the creative flair and of the constructive expertise of the Architect; in that case study the need to satisfy a design objective has entailed, on Vanvitelli's path, the design of an astonishing structural expedient.

Only the main formal relationships and most pertinent ones to the object of the present paper were reported, but many others could be observed in relation to the architectural distribution of the internal compartments e.g. in the inner main corridor can be observed that the inception of the ample string-course in stucco, highlighting the floor of the mezzanine, is proportioned to the corridor's rise. Speaking of the architectural hierarchy, it is interesting to note how great
significance is attributed to the serving environments such as the hallways; probably a sign of
how the previous monastic use required the attribution of more relevance to common spaces
rather than the personal ones, Fig. 5a.
Fractures on the masonry vaults of the main corridor of Palazzo Murcna are observable. On

this a monitoring system was implemented and permitted to figure out that, to date, the damage

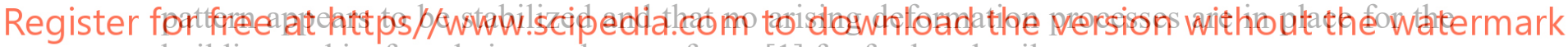
building and its foundations; please refer to [1] for further details.

The palace appears simple and rigorous by its bricks facades, based on rational splitting norms by means of openings and string-course, but instead lavish on the inside spaces adorned with frescoes, stuccos and extremely fine marble grit floorings, Fig. 5. In fact, above all, the PhD's hall, located on the noble floor of Palazzo Murena (the second one), and its vault have been completely frescoed by two Perugian painters in the $18^{\text {th }}$ century: Giovanni Bevilacqua for the decorative parts and Vincenzo Monotti for the figurative features, Fig. 6. About the floorings, including those of the mezzanine floor, they are made of marble grit, a technique much appreciated and requested throughout the $19^{\text {th }}$ century for the paving of architectural esteem buildings. They are characterized, in this case, by high joints (at the same level as the floor's surface) and by narrow grout lines combined with sharp edged square tiles in order to visually hide the mortar joints achieving a final result closer to the classic one entirely in marble and so without joints). Those choices, however, entails an almost "perfect" installation as any coplanar defects, even minor ones, could not be accepted either for aesthetic (emerging edges) or for functional reasons (steps in the flooring) denoting that this valuable flooring has been made by old craftsmen who were highly qualified, Fig. $5 \mathrm{~b}$. 


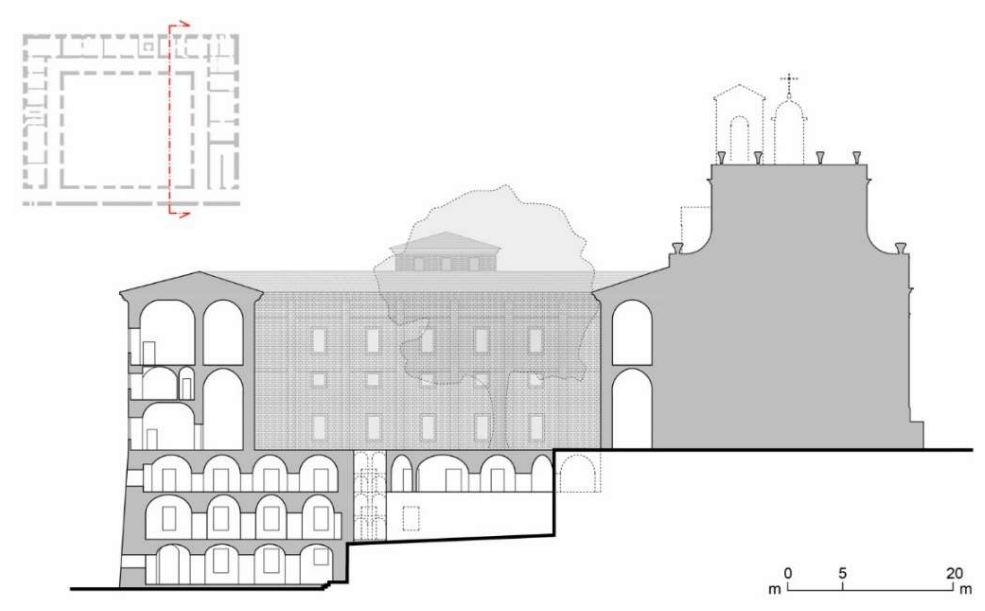

Figure 4: Cross-section of Palazzo Murena
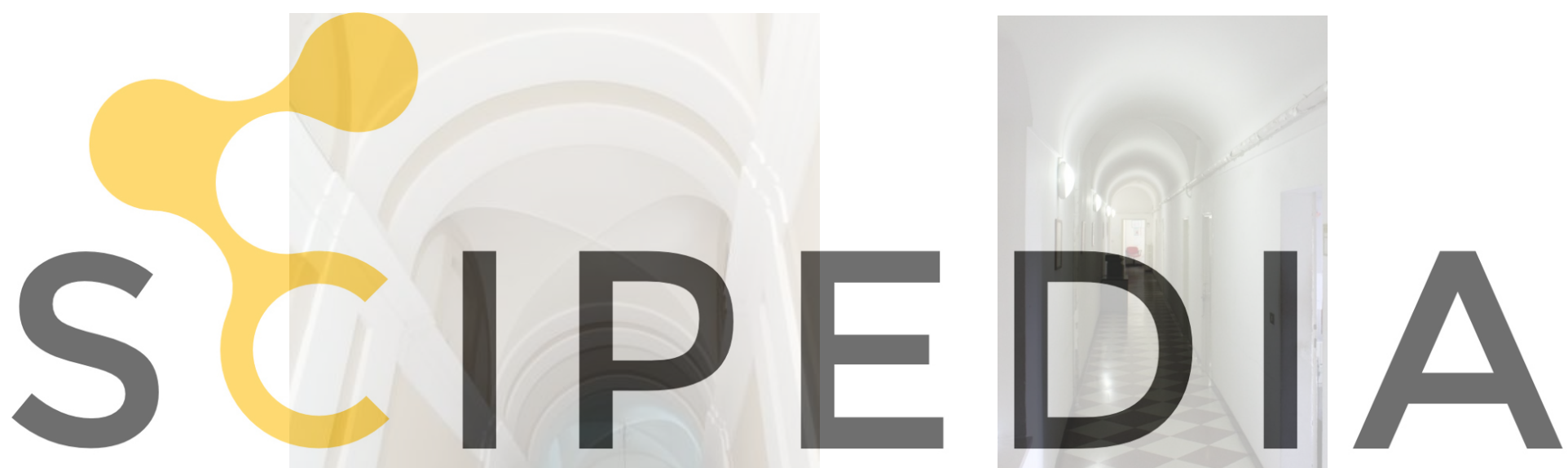

Register for free at https//www.scipedia.com to download the version without the watermark

(a)

(b)

Figure 5: Architectural arrangement of Palazzo Murena: a) detail of vaults and arcades covering the ground floor; b) view of the marble floorings at the mezzanine floor

\section{INTERVENTION OF STRUCTURAL STRENGTHENING}

In order to estimate the vulnerability of Palazzo Murena has been recently activated a research program. In a previous contribution [1] a preliminary seismic global analysis on a F.M.E. model (frame by macro-element), created using the data gained by means of innovative survey instrumentations, has allowed to identify in advance the most vulnerable portions of this ancient masonry building and to consequently finalize (and so reduce) the successive execution of the onerous and invasive investigation methodologies (like drills, endoscopies, flat jack tests etc.).

An experimental testing campaign has been conducted in order to assess the mechanical proprieties of the materials; moreover, a monitoring system has been implemented to check the mechanical behaviour of the building under environmental loading. 


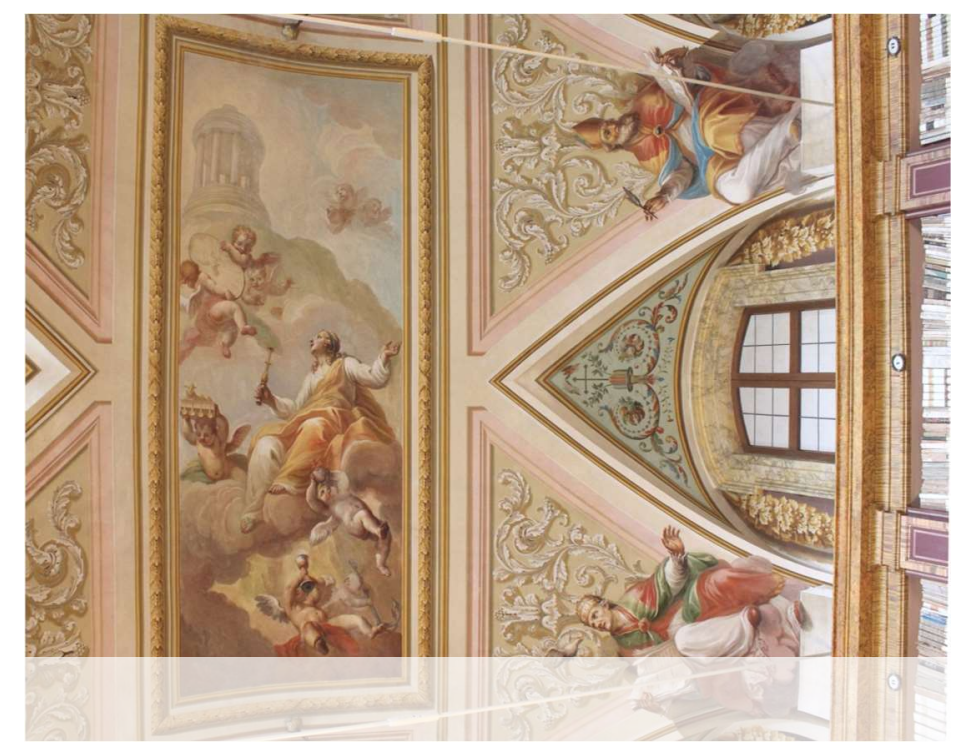

Figure 6: Ceiling of the PhD's hall of Palazzo Murena

On the basis of the increased level of knowledge deriving from the aforementioned experimental campaign, the preliminary numerical modelling has been refined in order to tune up the global seismic evaluation of the masonry building in its actual state. According to the

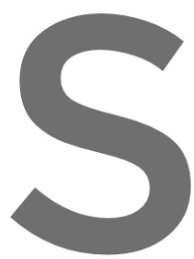
Italian Standard Codes from global point of view This is the case of mezza of a huge difference in th consists of load bearing $n$ $[2,3]$, the subsequent
but, at the sam time, th
he distribution of the str
masonry walls resting, in push-over analy
a targe geomet
uctural masses;
turn, on the und sis reveated the suffici
gh local vulnerable sub
ric irregularity and it is
moreover, it is vulner
derlying briek vaults an ficient safety
is the source
rable since it
and threfore
del, based on not vertically continuous to the foundation. Eventually, by means of a numerical model, based on the previous outcomes, the application of F.R.C.M. composite materials has been evaluated,

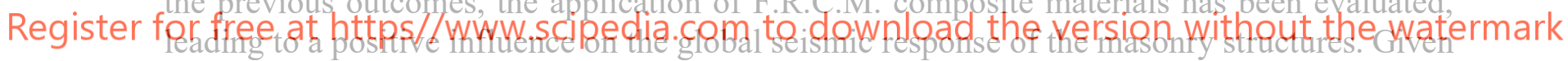

the constructive specificities and architectural uniqueness previously described, the structural strengthening has to assure the building's survival without penalize the role and the meaning it stood for during the centuries. In this framework in order to envisage intervention of structural strengthening the design approach, here proposed, is to not burden the masonry structure with extended interventions but rather in the localized retrofitting of only the most vulnerable structural elements. On this, the composite materials, that can be studied by analytical approach, with classical and non-classical theories $[12,13]$ or by numerical modelling, allow to fulfil the strengthening of ancient masonry buildings in compliance with their environmental, cultural and social value.

In response to such outcomes, a real reinforcement plan, conceiving the design of F.R.C.M. reinforcements, is proposed without put on the line socio-architectural prestige of the building; circumstance also linked to the accessibility and to the function of such a strategic edifice. The intervention consists in a high performance fiber mesh coupled with an inorganic matrix (mortar), used instead of the traditional epoxy resins, proper of fiber reinforced plastics (F.R.P. systems), in order to obtain a real reinforced plaster $[3,9,10]$. 
On heritage buildings, the importance of the structural strengthening runs no deeper than the preservation of architectural value of the artefacts; also in the present case the uniqueness of masonries, especially with respect to arches [11], conditioned and inspired the intervention strategies. Focusing the attention on the walls of the mezzanine floor, made of bricks and lime mortar, the application of the composite material allows to avoid the burden of the existing masonry structures with the additional weight and to avert damages to fine marble flooring and other valuable elements during the building work. In particular, the localization of F.R.C.M. on those inner walls guarantees to strength them regarding the bending and the shear actions, Fig. 7. Regarding the design and verification criteria, the technical guidelines provided by the CNR [8] have been followed; in particular the rules described in the paragraph $\S 4.1 .1$ of the same. In addition the implementation steps and criteria have been thrust toward the innovative design rules promoted by the scientific and technical literature $[14,15,16]$. For design and verification purposes the materials of the Kimia S.p.A. [14], and the relative mechanical parameters Tabs. 1-2, were taken as reference including the use of the bi-directional basaltic net KIMITECH BS ST 400, the matrix in mortar M15/F. In addition, the use of transversal connectors known as "fiocchi", one for each 4-5 $\mathrm{m}^{2}$, in order to create artificial through stones within the walls, and to create a sandwich masonry-reinforced plaster panel was intended, Fig. 8a. With respect to such element the product Kimisteel FIOCCO GLV has been chosen, the latter is composed by a "sock" containing unidirectional galvanized steel-zinc filaments. For such element the designed diameters is $\phi 12[\mathrm{~mm}]$; entailing for its insertion the creation of wall drills of diameter

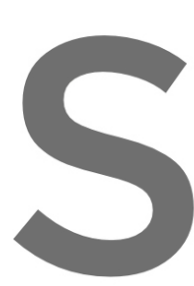
of between 16 and $20[\mathrm{~mm}] \mathrm{f}$

\section{locations of the differ} implementation modali will be inferior to 30
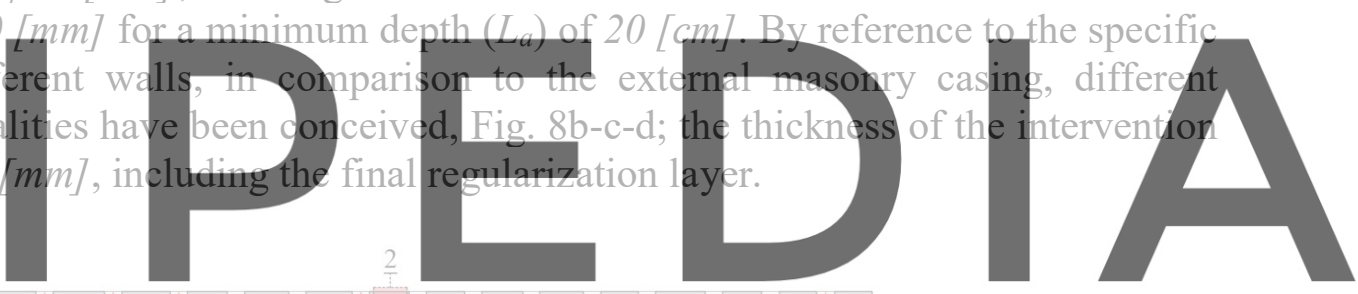

Register for free at https//WwW.Scipedia:com to download the version without the watermark

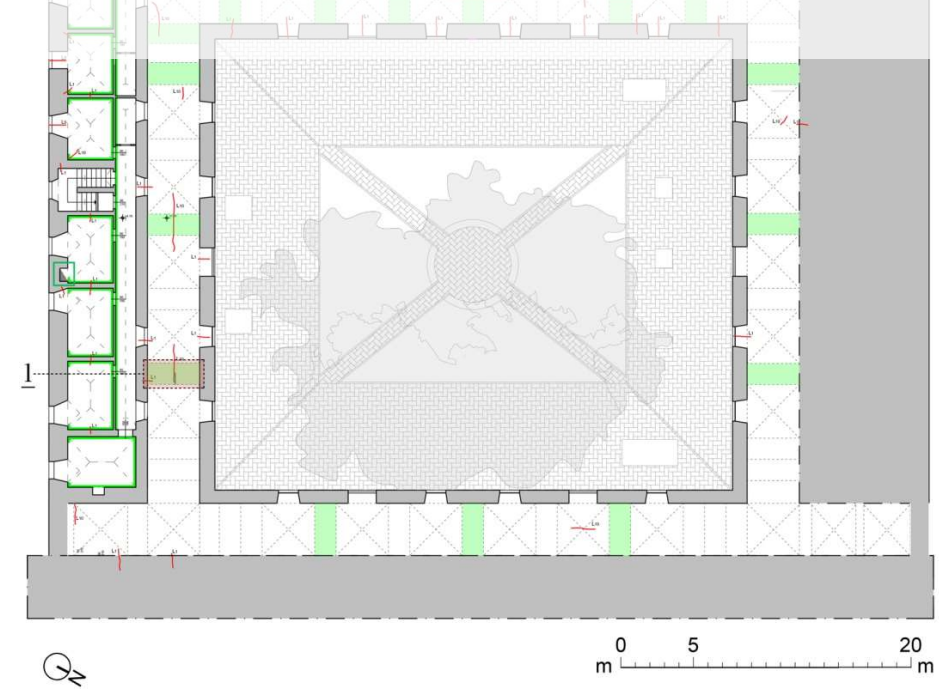

Figure 7: Plan of the mezzanine floor with the proposed interventions in F.R.C.M. (characterized in green). 1) Interventions on the arcades covering the main aisle; 2) Interventions on the inner walls of the mezzanine floor 
As observed during the survey, the main corridor on the ground floor is covered by cross vaults spaced out by decorated arcades. In addition, a stucco moulding, placed at the height of springer, runs along the entire length of the building and furthermore the walls are adorned by half pilasters which also develop on the arches giving rhythm to the inner walls of the building. During the monitoring, which is always an important item when dealing with historical structures [17], it was possible to observe how the crack pattern detected on the vaults covering the quadrangular corridor is not representing a state of danger, however its presence testifies the memory of the numerous earthquakes that in past and recently times involved the structure [1]. On this, in a future excerpt of the intervention plan their renewal will be foreseen in the perspective of a re-garnish of whole Palazzo Murena. Aiming at the reinforcement of the arcades the application of F.R.C.M. was envisaged according to a specific designed method, taking into account the architectural value of the mouldings, which refers to the design tips published by the CNR [8] and to the latest analytical and experimental outcomes available in the scientific literature $[18,19]$.

Table 1: Mechanical properties of the bidirectional basaltic fiber net, KIMITECH BSS ST 400: $\rho_{f i b}\left[\mathrm{~g} / \mathrm{cm}^{3}\right]$ density, $E[G P a]$ elastic modulus, $\sigma_{u}[M P a]$ ultimate tensile strength, $\varepsilon[\%]$ breaking strain, $g$

$[\mathrm{g} / \mathrm{mq}]$ grammage, $w_{s}[\mathrm{~g} / \mathrm{mq}]$ weigth of tissue starching, $D_{m}[\mathrm{~mm}]$ dimension of the mesh, $t[\mathrm{~mm}]$ thickness of the net, $t_{f}^{*}[\mathrm{~mm}]$ equivalent thickness of the net, $A_{r}[\mathrm{mmq} / \mathrm{m}]$ resistant area, $Q[\mathrm{kN} / \mathrm{m}]$ tensile breaking load of the warp, $b_{f}[\mathrm{~mm}]$ single strip width. *Intended for each warp direction
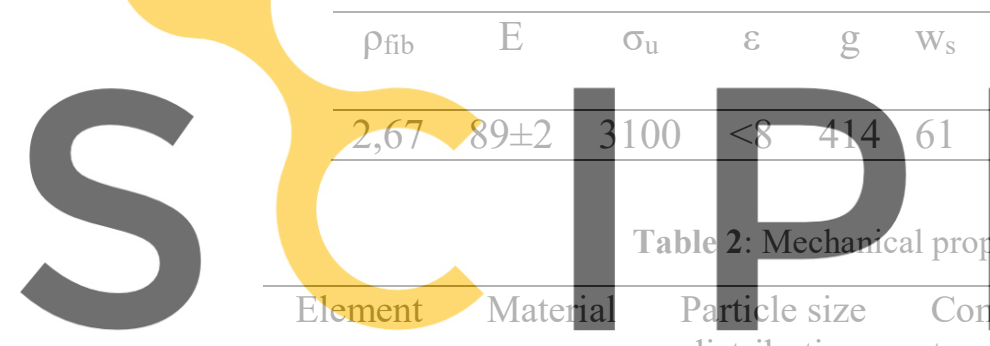

distribution

strength $[\mathrm{MPa}]$

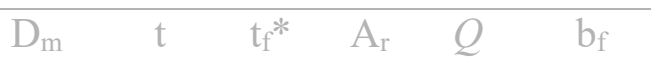

free at https//www.scipedia.con
Mortar - Lime maximum Matrix

inorganic mortar $\mathrm{M} 15 / \mathrm{F}$
$1,20 \mathrm{~mm}$ at $28 \mathrm{dd}>15$

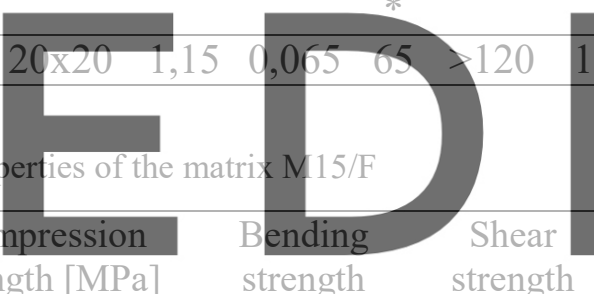

strength

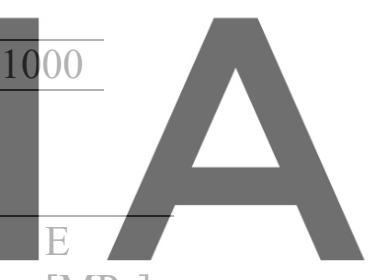

[MPa]

[M.Pa 0,159600

(with

masonry

- EN

711)

Each arch presents a tripartite moulding; the first phase of the proposed design plan consists of the removal of a small stucco-band from the two most protruding portions of the decoration in order to reach the resistant part of the arch constituted by the masonry. Then, with the same superficial treatment described previously, the F.R.C.M. material is applied in the groove using the aforementioned mortar but employing, this time, a unidirectional stainless steel fiber reinforcement fabric, Kimisteel INOX 800, located with respect to its frame along the arch's profile; its high-strength properties are reported within Tab. 3. Regarding the arcades the thickness of the reinforcement intervention should be around $6 / 7[\mathrm{~mm}]$ and requires the use of the aforementioned typology of connector in order to provide the coupling to the masonry supports. Finally, for each garnish, the two lateral stucco strips, remainders of the pre-existing decoration, will be used by restorers as reference in order to restore the mouldings in their 
entirety, guaranteeing an exterior appearance akin to the original result, Fig. 9. It should be noted that this intervention plan, aimed at the safeguard of this architectural asset, is conceived with methods and technologies which allow to not penalize the strategic function of this building during the F.R.C.M. application phases.

In fact, unlike other strategies of structural intervention, the designed strengthening actions do not lead to the total closure of the University "headquarter" and its offices. In turn some offices, at the mezzanine floor, or part of the main corridor at the ground floor will be close and by the time installations are completed the small construction sites will move to the next spaces; permitting to reopen each time few retrofitted portion of structure in order to accommodate the public, the students and the employees.
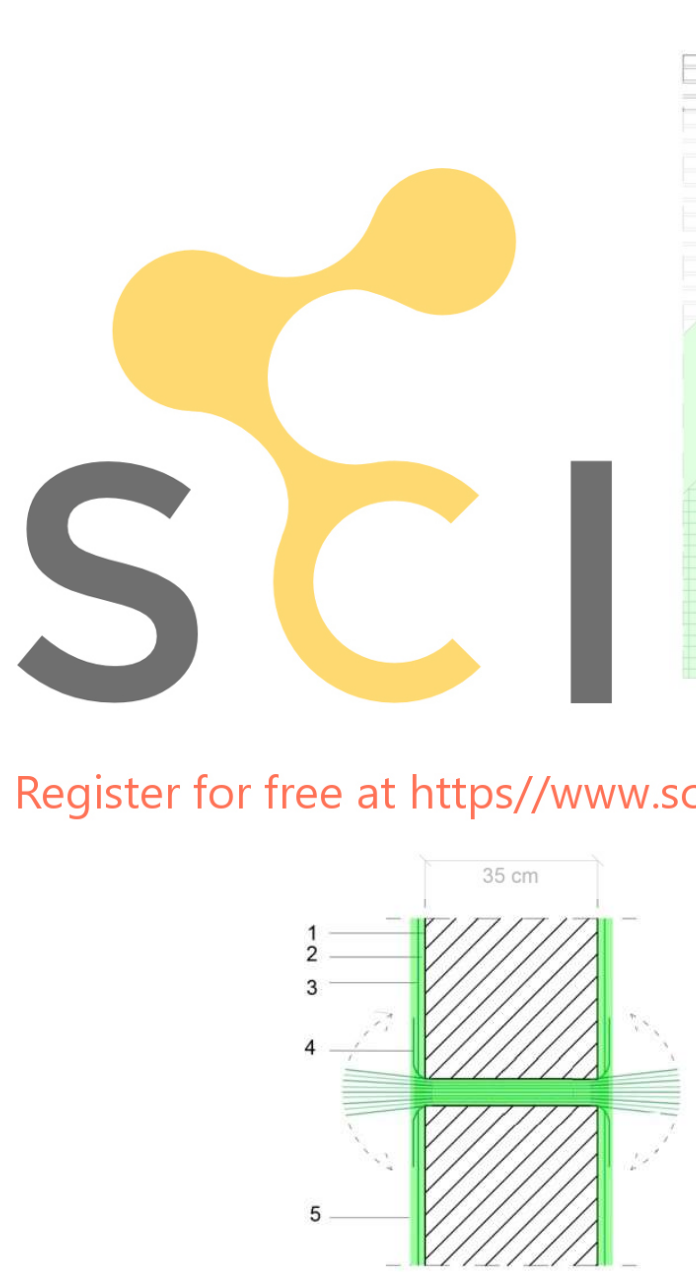

(b)
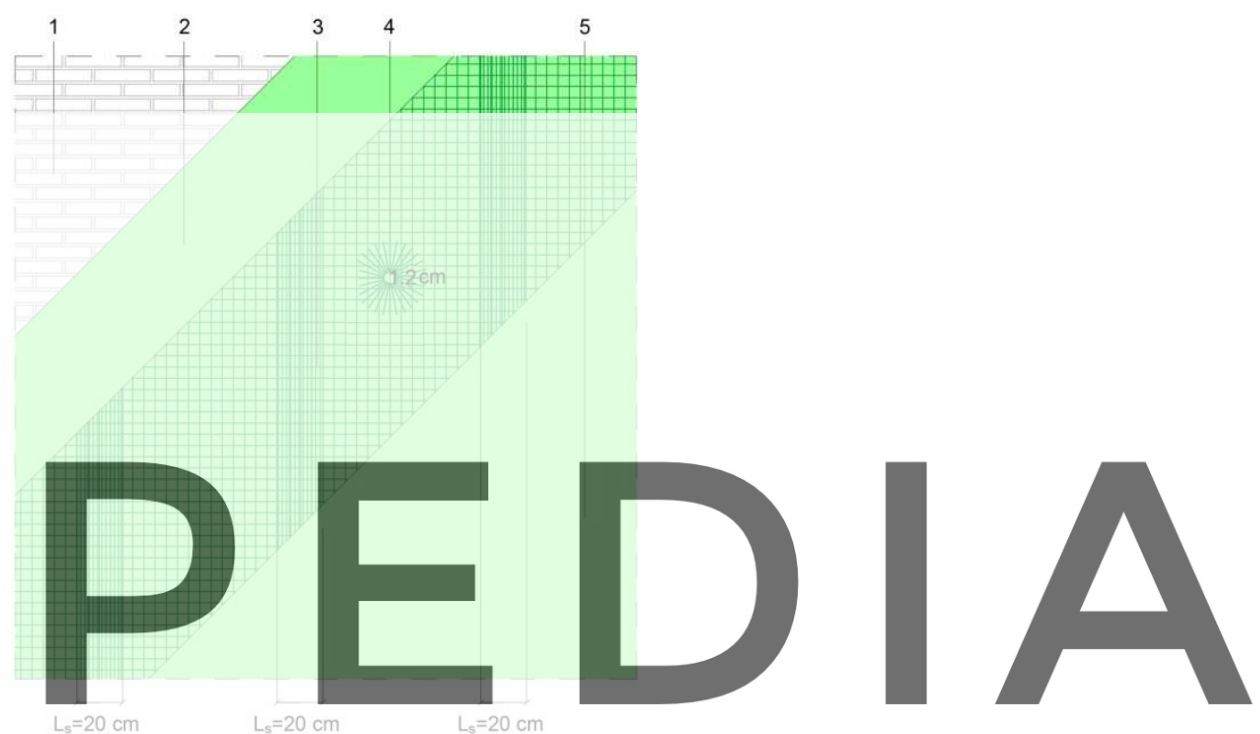

superimposition of fiber net band

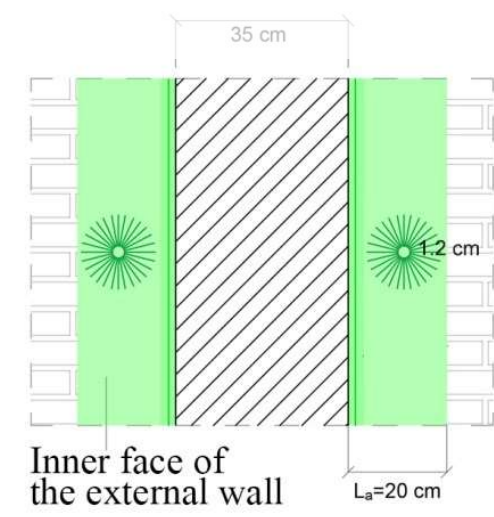

(c)

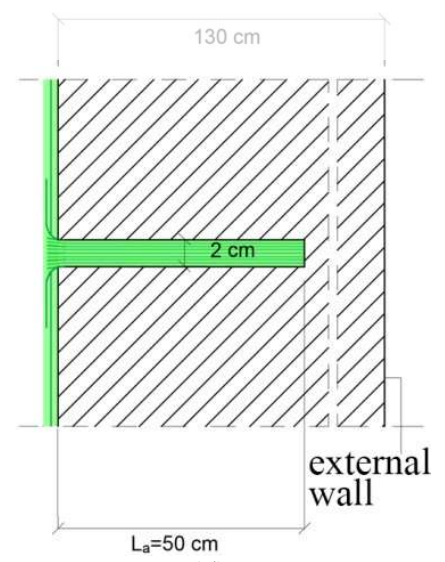

(d)

Figure 8: Improvement intervention with F.R.C.M. a) Application procedure, scale 1:40. Technical details of the reinforced walls, scale 1:20: b) General section of a reinforced internal wall with transversal connectors;

c) Section of a reinforced internal wall; d) Section of an external wall highlighting the corner joints between reinforced internal walls and perimetral one 
Table 3: Unidirectional high-strength stainless steel fiber fabric, Kimisteel INOX 800 ST1-0619: $\rho\left[\mathrm{g} / \mathrm{cm}^{3}\right]$ density, $E_{w}[\mathrm{GPa}]$ elastic modulus of wires, $R_{\text {wire }}[\mathrm{MPa}]$ wire resistance, $\varepsilon[\%]$ breaking strain, $\mathrm{N}_{\mathrm{y}}$ number of yelds for each wire, $D_{s}[\mathrm{~mm}]$ diameter of strands, $A_{s}[\mathrm{mmq}]$ strands resistant area, $Q_{w}[N]$ wire minimum breaking load, $b_{f}[\mathrm{~mm}]$ single strip width, $g[\mathrm{~g} / \mathrm{mq}]$ grammage, $w_{s}[\mathrm{~g} / \mathrm{mq}]$ weigth of tissue starching, $D_{m}[\mathrm{~mm}]$ dimension of the mesh, $t_{t}[\mathrm{~mm}]$ steel theoric thickness, $t_{f}{ }^{*}[\mathrm{~mm}]$ equivalent thickness of the net, $A_{r u}[\mathrm{mmq} / \mathrm{m}]$ resistant area for units of length, $R_{u}[\mathrm{~N} / \mathrm{mm}]$ unitary resistance for units of fabric

\begin{tabular}{cccccccccccccc}
\hline$\rho$ & $\mathrm{E}_{\mathrm{w}}$ & $\mathrm{R}_{\mathrm{w}}$ & $\varepsilon$ & $\mathrm{N}_{\mathrm{y}}$ & $\mathrm{D}_{\mathrm{s}}$ & $\mathrm{A}_{\mathrm{s}}$ & $\mathrm{Q}_{\min }$ & $\mathrm{b}_{\mathrm{f}}$ & $\mathrm{g}$ & $\mathrm{D}_{\mathrm{m}}$ & $\mathrm{t}_{\mathrm{t}}$ & $\mathrm{A}_{\mathrm{ru}}$ & $R_{u}$ \\
\hline 7,85 & 210 & 2000 & 0,95 & 16 & 1 & 0,483 & 930 & $100-$ & 800 & $20 \times 2$ & 0,07 & 77.33 & 160 \\
& & & & & & & & 300 & & 0 & 7 & 8 & \\
\hline
\end{tabular}

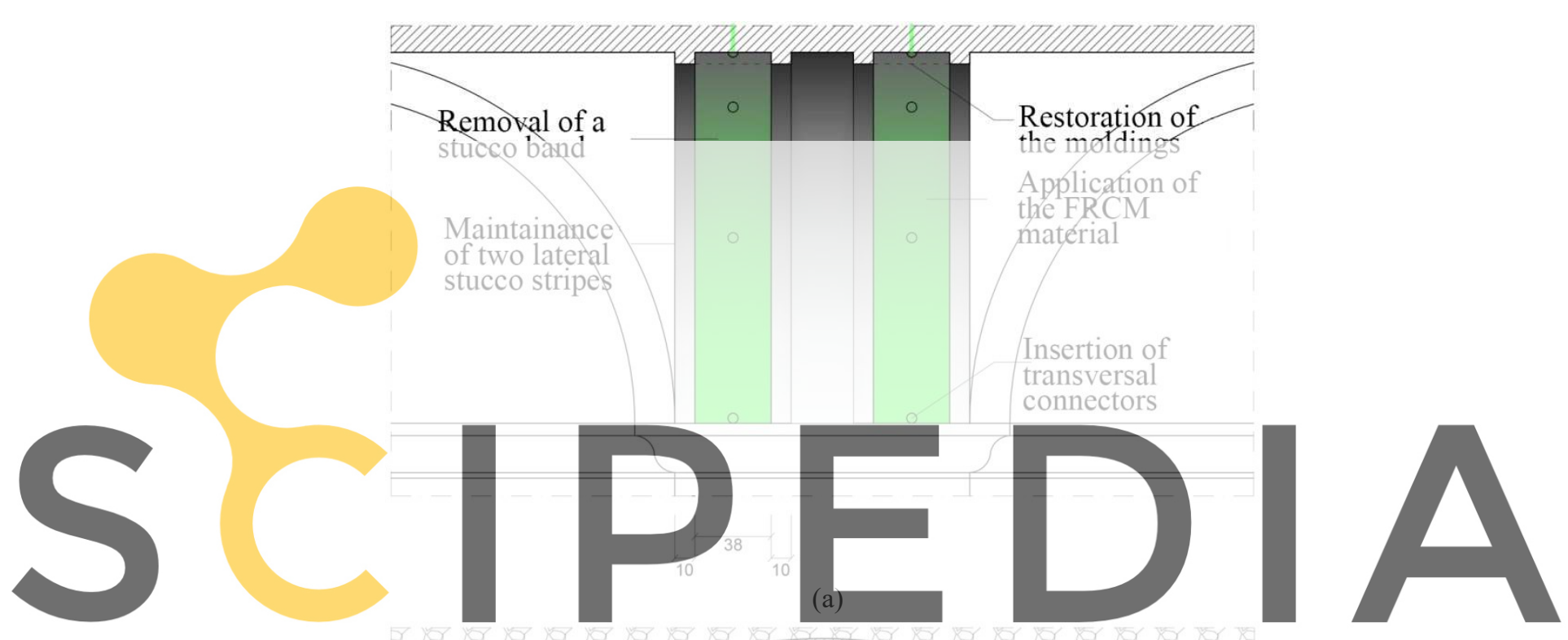

Register for free at https//www.scipedia.com to download the version without the watermark
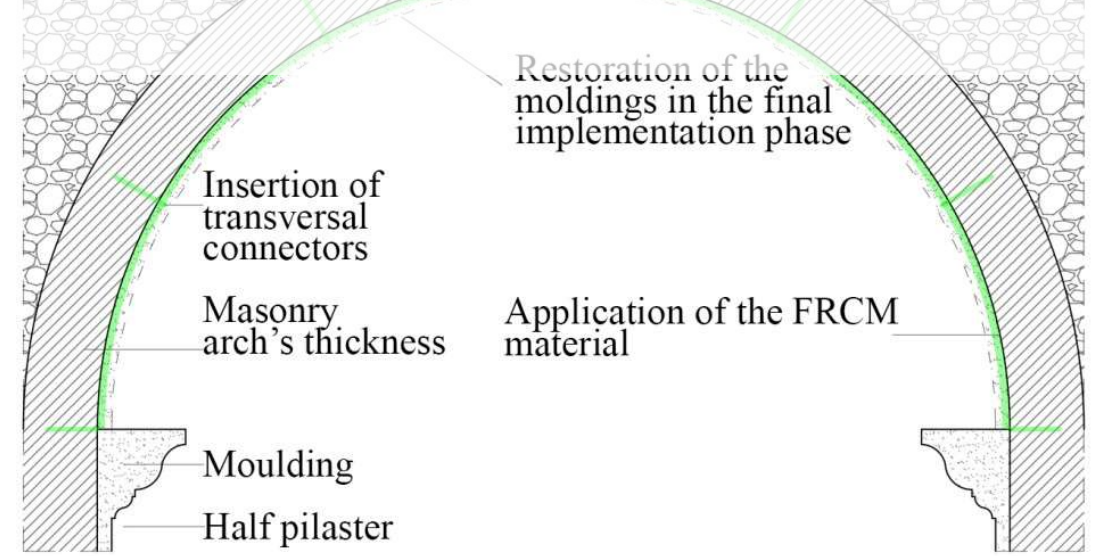

(b)

Figure 9: Improvement intervention with F.R.C.M. and its application procedure technical detail of the reinforced plaster with fiber transversal connector, scale 1:40. a) Transversal section of an arch;

b) Longitudinal section of an arch 


\section{CONCLUSIONS}

- $\quad$ Starting from a historical study and accurate survey and taking into account the results of vulnerability analysis, in the present paper a strengthening design approach in regard to the conservation of Palazzo Murena in Perugia has been illustrated;

- In order to preserve the constructive specificities and architectural uniqueness of the building, a local reinforcement intervention is proposed for the walls of the mezzanine floor and for the arches of the main corridor on the ground floor. This consists of the application of F.R.C.M. to obtain a reinforced plaster which assure an adequate strength, without increasing the weight of the masonry structure and therefore without increase of the seismic vulnerability;

- The ongoing research will take into account experimental testing and numerical analyses to check the effectiveness of the proposed strengthening interventions also with respect to the implementation modalities.

Acknowledgments. The support received from the University of Perugia and the collaboration of its Technical Office, represented by L. Palma and B. Buonforte, are thanked.

\section{REFERENCES}

[1] Liberotti, R., Cluni, F. and Gusella V. Vulnerability and seismic improvement of architectural heritage: the case of Palazzo Murena. Earthquakes and Structures (2020) 18 (3): 321-335.

[2] NTC 2018. Decreto Ministeriale 14 Gennaio2018, Aggiornamento delle «Norme tecniche per le costruzioni», Supplemento ordinario alla "Gazzetta Ufficiale,, n. 42 del 20 febbraio 2018 - Serie generale, Ministero delle Infrastrutture e dei Trasporti; Roma, Italy.

[3] Circ. No7 (2019), Circolare del Ministero delle infrastrutture e dei trasporti 21 gennaio 2019, n. 7 C.S.LL.PP., Istruzioni per l'applicazione dell' «Aggiornamento delle "Norme tecniche per le costruzioni"» di cui al decreto ministeriale 17 gennaio 2018., Supplemento ordinario alla "Gazzetta Ufficiale" n. 35 del 11 febbraio 2019 - Serie generale, Ministero delle Infrastrutture e dei Trasporti; Roma, Italy.

[4] Rotili M. Vita di Luigi Vanvitelli. Timawo e Burgo, Napoli, Italy, (1975).

[5] Chiacchella R. Un quartiere e la sua storia: La Conca di Perugia. La Conca di Perugia itinerario per una conoscenza e una proposta. Quaderni Regione dell'Umbria, Perugia: 97100, (1975).

[6] Dozza, G. Università Di Perugia. Sette Secoli Di Modernità 1308-1976. Delta Editrice, Perugia, Italy, (1975).

[7] Sorignani, C. UNI|TECA Progetto architettonico di trasformazione in Gipsoteca dell'edificio sede dell'ufficio Economato dell'Università degli Studi di Perugia. Master thesis, University of Perugia, Perugia, Italy, (2018).

[8] CNR-DT 215/2018, Istruzioni per la Progettazione, l'Esecuzione ed il Controllo di Interventi di Consolidamento Statico mediante l'utilizzo di Compositi Fibrorinforzati a Matrice Inorganica, CNR, 2018.

[9] Lignola, G.P., Di Ludovico, M., Prota, A., Aiello, M. A. and Varum H. Design rules for inplane shear strengthening of masonry with FRCM. 9th International Conference on FRP Composites in Civil Engineering CICE 2018, Paris, France, July. 
[10] Lourenço, P.B., Oliveira, D.V., Leite, J.C., Ingham J.M., Modena, C. and da Porto, F. Simplified indexes for the seismic assessment of masonry buildings: International database and validation. Engineering Failure Analysis (2013) 34: 508-605.

https://doi.org/10.1016/j.engfailanal.2013.02.014

[11] Cavalagli, N., Gusella, V. and Liberotti, R. The Role of Shape Irregularities on the Lateral Loads Bearing Capacity of Circular Masonry Arches. In: Carcaterra A., Paolone A., Graziani G. (Eds) Proceedings of XXIV AIMETA Conference 2019. AIMETA 2019. Lecture Notes in Mechanical Engineering. Springer, Cham, (2020), pp. 2069-2081.

[12] Autuori, G., Cluni, F., Gusella, V. and Pucci, P. Effects of the fractional laplacian order on the nonlocal elastic rod response. ASCE-ASME Journal of Risk and Uncertainty in Engineering Systems, Part B: Mechanical Engineering 3 (3) (2017) September, Article number 030902

[13] Autuori, G., Cluni, F., Gusella, V. and Pucci, P. Mathematical models for nonlocal elastic Composite materials. Advan. Nonlin. Anal. (2017) 6 (4): 355-382. https://doi.org/10.1515/anona-2016-0186.

[14] Kimia (2019), Interventi-strutturali-resine-tessuti-pultrusi/frcm; Kimia S.p.a., P.te Felcino (Perugia), Italy. www.kimia.it

[15] Pourfalah S., Cotsovos D.M. and Suryanto B. Modelling the out-of-plane behaviour of masonry walls retrofitted with engineered cementitious composites. Computers and Structures (2018) 201: 58-79.

[16] D'Ambra, C., Lignola, G.P., Prota, A., Sacco E. and Fabbrocino F. Experimental performance of FRCM retrofit on out-of-plane behaviour of clay brick walls. Composites Part B (2018) 148: 198-206.

[17] Gioffré, M., Gusella, V. and Cluni, F. Performance evaluation of monumental bridges: Testing and monitoring 'Ponte delle Torri' in Spoleto. Structure and Infrastructure Engineering (2008) 4 (2): 95-106.

[18] Zampieri, P., Gonzalez-Libreros, J., Simoncello, N. and Pellegrino C. Strengthening of Masonry Arches with FRCM Composites: A Review. Key Engineering Materials (2019) 817: 251-258. https://doi.org/10.4028/www.scientific.net/kem.817.251.

[19] Alecci, V., Focacci, F., Rovero, L., Stipo, G., Mantegazza, G. and de Stefano M. FRCM Composites for Strengthening of Brick Masonry Arches. Key Engineering Materials (2017) 747: 174-181. https://doi.org/10.4028/www.scientific.net/kem.747.174. 